\title{
Functional anatomy of the ovaries of pregnant and lactating Cape porcupines, Hystrix africaeaustralis
}

\author{
R. J. van Aarde and J. D. Skinner \\ Mammal Research Institute, University of Pretoria, Pretoria 0002, South Africa
}

\begin{abstract}
Summary. The constituent cell types of the ovary of the porcupine were similar to those of New World hystricomorph rodents and accessory corpora lutea and luteal bodies were formed through the luteinization of the membrana granulosa or theca interna of antral follicles. All luteal bodies were histologically similar. The total volume of luteal tissue per female was not affected by fetal age and was unrelated to circulating concentrations of maternal plasma progesterone. Maternal plasma progesterone concentrations were correlated with fetal age. Follicular activity occurred throughout pregnancy but was not affected by fetal age or related to circulating values of oestradiol-17 $\beta$. The formation of accessory corpora lutea during pregnancy is regarded as important in supplementing progesterone during pregnancy.
\end{abstract}

\section{Introduction}

Published information on reproduction of female Old World porcupines (Family Hystricidae) is limited to that on the crested porcupine, Hystrix cristata (Weir, 1967), Himalayan porcupine, $H$. hodgsoni (Gosling, 1980), Indian porcupine, H. indica (Thomè \& Thomè, 1980) and the Cape porcupine, $H$. africaeaustralis (Skinner, van Aarde \& van Jaarsveld, 1984; van Aarde, 1985a, b). The functional anatomy of the hystricomorph ovary, and especially that of New World species, was reviewed by Weir \& Rowlands (1974). Modifications in the ovary and placenta of New World hystricomorph rodents apparently enhance the synthesis of progesterone for the maintenance of gestation (Tam, 1974) and accessory corpora lutea are functionally equivalent to the corpora lutea of pregnancy, acting as additional sources of progesterone (Heap \& Illingworth, 1974; Tam, 1974). The reproductive processes of the female Cape porcupine conform to the general hystricomorph pattern (van Aarde, 1984, 1985a) but no published information is available on the functional activities of the ovary of this species.

In the present study we have examined the macro- and microscopic anatomy of the ovary of the female Cape porcupine and the relationship(s) between the presence of ovarian structures and circulating concentrations of progesterone and oestradiol- $17 \beta$.

\section{Materials and Methods}

Ovaries and blood samples were collected from 54 females killed on the Tussen-die-Riviere Game Farm $\left(30^{\circ} 25^{\prime} \mathrm{S}, 26^{\circ} 12^{\prime} \mathrm{E}\right)$, South Africa, as part of the cropping programme. Females were recorded as lactating when milk could be expressed from their teats and the condition of the vaginal membrane was recorded as either perforated (in oestrus) or unperforated. Fetuses and ovaries were weighed before fixation in AFA (mixture of $95 \%$ ethanol, $40 \%$ formalin, glacial acetic acid and distilled water; $3: 1: 1: 5$ by vol.). After centrifugation plasma fractions were stored at $-20^{\circ} \mathrm{C}$ until assayed for steroid hormone values. Fetal age was determined using the formula $\sqrt[3]{\mathrm{W}=a\left(t-t_{0}\right)}$ 
where $\mathrm{W}=$ fetal weight, $a=$ specific growth velocity, $t=$ gestation age in days, and $t_{0}=$ the calculated intercept on the age axis (Huggett \& Widdas, 1951). The theoretical value was calculated using a birth weight of $351 \mathrm{~g}$, where $t=93.5$ days (van Aarde, 1985a), and $t_{0}$ as $t \times 0.3$ (see Huggett \& Widdas, 1951).

Fixed ovaries were weighed, and serially sectioned at $5 \mu \mathrm{m}$ along the longitudinal axis after routine dehydration and embedding in paraffin wax. Every tenth section was mounted on a glass microscope slide and stained, using haematoxylin and eosin. Diameters of antral follicles and corpora lutea were measured microscopically as the greatest length on any two perpendicular axes. These values $\left(r_{1}\right.$ and $\left.r_{2}\right)$ were used to estimate volumes by means of the formula $\frac{4}{3} \pi r_{1} r_{2}\left(\frac{r_{1}+r_{2}}{2}\right)$. Accessory corpora lutea were distinguished from primary corpora lutea by their smaller size and the presence of degenerating ova or remains of a zona pellucida (Rowlands, Tam \& Kleiman, 1970; Harrison \& Weir, 1977). Other units of luteal tissue are referred to as 'luteal bodies' (see Harrison \& Weir, 1977).

\section{Measurement of plasma steroid concentrations}

Progesterone. Progesterone was measured in plasma extracts by radioimmunoassay as described by van Aarde $(1984,1985 a)$. Specificity of the antiserum was described by Furr (1973) and cross-reactions of other steroids were: 11 $\alpha$-hydroxyprogesterone, $85 \% ; 17 \alpha$ hydroxyprogesterone, $12.5 \%$; $5 \beta$-pregnane-3,20-dione, $12.5 \%$; $5 \alpha$-pregnane-3,20-dione, $3.0 \%$;

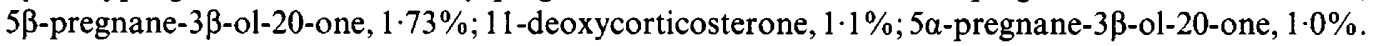

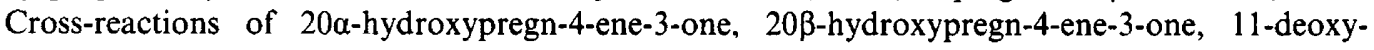
cortisol, testosterone, androstenedione, pregnenolone, $5 \beta$-pregnane- $3 \alpha, 20 \alpha$-diol oestradiol-17 $\beta$ were less than $0 \cdot 70 \%$.

Sensitivity of the assay, defined as twice the standard deviation of blank values, ranged from 0.16 to $0.73 \mathrm{ng} / \mathrm{ml}(0.49 \pm 0.21$ s.d.; $n=7)$. Ten buffer blanks measured during the assays contained $0.46 \pm 0.26 \mathrm{ng}$ progesterone equiv. $/ \mathrm{ml}$.

Extraction efficiency was affected by plasma volume and plasma progesterone concentrations and decreased exponentially with an increase in progesterone values. Recovery estimates varied from 81.0 to $94.1 \%$ (mean $86.6 \pm 4.85 ; n=7$ ) for samples containing 0.5 to $5.0 \mathrm{ng}$ progesterone $/ \mathrm{ml}$ and from 61.1 to $77.2 \%$ (mean $69.3 \pm 4.43 ; n=10$ ) for samples containing $>5.0$ and $<15.0 \mathrm{ng}$ progesterone $/ \mathrm{ml}$ plasma. Recovery estimates for plasma samples containing $>15.0$ and $<160.0 \mathrm{ng}$ progesterone $/ \mathrm{ml}$ varied from $12 \cdot 5$ to $54 \cdot 6 \%(n=40)$ and were also affected by the volume of plasma extracted. All these samples originated from pregnant females and the low recovery estimates may be ascribed to the presence of progesterone-binding plasma proteins (Challis, Heap \& Illingworth, 1971; Heap, Ackland \& Weir, 1981; van Aarde \& Potgieter, 1986). The addition of $0.1 \mathrm{ml} \mathrm{NaOH}$ $(0.6 \mathrm{~mol} / 1) 10 \mathrm{~min}$ before extraction increased recovery estimates in these samples to $69.6 \pm 8.87 \%$. The intra-and interassay coefficients for variation, calculated according to the method of Jeffcoate (1981), were 4.3 and $9.7 \%$ respectively. The interassay variation for a plasma sample containing $6.6 \mathrm{ng}$ progesterone $/ \mathrm{ml}$ included in all assays was $7.6 \%$.

Oestradiol $-17 \beta$. The protocol for determining plasma levels of unconjugated oestradiol-17 $\beta$ was similar to that described by Abraham (1976) but steroids were not purified and separated by chromatography after extraction (see van Aarde, 1985a). The specificity of the antiserum, raised in a rabbit against oestradiol-6-(O-carboxymethyl)oxime-bovine serum albumin conjugate, has been described by the supplier (R. P. Millar, Department of Chemical Pathology, University of Cape Town) and cross-reactions of other steroids were: oestrone, $0.01 \%$; pregnanediol, corticosterone,

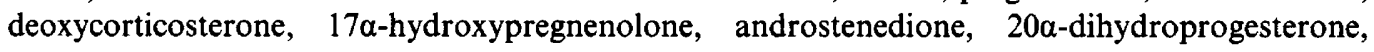
progesterone, testosterone and cortisol, $0.001 \%$.

The sensitivity of the assay, defined as twice the standard deviation of values obtained from buffer blanks, ranged from 3.7 to $15.8 \mathrm{pg} / \mathrm{ml}$ (mean $11.7 \pm 3.9 \mathrm{pg} / \mathrm{ml}$ ). Buffer blanks measured in 
duplicate during 8 assays contained $8 \cdot 3 \pm 2 \cdot 8 \mathrm{pg}$ oestradiol- $17 \beta$ equiv./ml. Extraction efficiency varied from $85 \cdot 1$ to $96 \cdot 8 \%$ (mean $91 \cdot 4 \pm 4 \cdot 3 \% ; n=8$ ).

The intra- and interassay coefficients of variation calculated according to the method of Jeffcoate (1981) were 2.4 and $16.2 \%$ respectively. Interassay variation, for a sample included in 8 assays which contained $32 \cdot 6 \pm 3 \cdot 1 \mathrm{pg} / \mathrm{ml}$, was $9 \cdot 4 \%$.

\section{Results}

\section{Description of the ovary}

Macroscopic appearance. The ovoid, flattened ovaries were not enclosed by a bursa and had a relatively smooth outer surface. Corpora lutea and follicles did not protrude above the surface and the latter were often visible as transparent bodies within the substance of the ovary. The ovary was attached to the mesovarium along its length. The fimbriated end of the oviduct also extended over the total length of the ovary. The oviduct had a well-developed cranial loop and was convoluted over its entire length.

Left and right ovaries did not differ significantly in weight (paired $t=-0 \cdot 75$; d.f. $=47$ ) and combined ovarian weights of pregnant females (mean $0.78 \pm 0.25 \mathrm{~g} ; \mathrm{N}=9$ ) did not differ significantly $(t=0.59$; d.f. $=14)$ from those of lactating (mean $0.71 \pm 0.23 \mathrm{~g} ; \mathrm{N}=7$ ) or reproductively inactive (mean $0.64 \pm 0.38 \mathrm{~g} ; \mathrm{N}=7$ ) adults.

Microscopic anatomy. The constituent cell types of the ovary of the porcupines were similar to those described by Weir (1967), Weir \& Rowlands (1974) and Harrison \& Weir (1977) for hystricomorph rodents in general. Rete ovarii and tubules of the oöphoron were not detected during the present study. Primary oocytes were situated in the cortex of the ovary below the tunica albuginea and primordial follicles occurred predominantly in the peripheral zone of the cortex. Antrum formation and maturation of follicles occurred throughout the cortex and medulla of the ovary and the largest follicles were approximately $2.53 \mathrm{~mm}$ in diameter, most varying from 0.96 to $1.35 \mathrm{~mm}$. Newly formed corpora lutea varied from 2.92 to $4.74 \mathrm{~mm}$ in diameter.

The nuclei of the basal layer of cells of the membrana granulosa of antral follicles were noticeably aligned and the theca interna was well developed. The theca externa was less prominent. Transformation of follicles into accessory corpora lutea by luteinization or into interstitial tissue occurred in all stages of follicular development, the latter being prominent in the ovaries of immature females. Primordial and antral follicles with more than one oocyte were common in the ovaries of immature females. Most of the volume of these ovaries consisted of developing and degenerating antral follicles of various sizes.

Various types of corpora lutea were identified; these included the corpus luteum graviditatis, corpus haemorrhagicum, corpora lutea accessoria, 'luteal bodies' and corpora atretica. Accessory corpora lutea and corpora atretica were formed through luteinization of the membrana granulosa or theca interna respectively. Corpora lutea resulting from the luteinization of ovulated follicles were larger than those formed from unovulated follicles. All these luteal bodies were histologically similar.

\section{Functional activity of the ovaries}

During pregnancy. Ovaries of pregnant females consisted predominantly of primary corpora lutea (CL), accessory corpora lutea, and corpora atretica of various sizes. The total number of luteal units (corpora lutea and the 'luteal bodies') per ovary varied from 1 to 11 and from 5 to 19 per animal, decreasing with an increase in fetal age (Fig. 1a).

The number of positively identified primary corpora lutea per female varied from 1 to 4 , suggesting a mean ovulation rate of $2.5 \pm 0.9(\mathrm{~N}=12)$. Primary corpora lutea persist throughout 
pregnancy with their numbers corresponding to the number of fetuses in $7(58 \cdot 3 \%)$ of 12 females. Ovum mortality in the remainder, as suggested by the difference between the number of primary corpora lutea and fetuses, varied from 1 to 2 (mean $1.6 \pm 0.55$ ). The volume of primary corpora lutea for all animals combined varied from 1.02 to $36.11 \mathrm{~mm}^{3}$ (mean $9.33 \pm 7.39 ; n=31$ ) and these were significantly $(P<0.001)$ larger than other luteal bodies, these varying from 0.06 to $6.21 \mathrm{~mm}^{3}$ (mean $1.07 \pm 1 \cdot 50 ; n=73$ ).
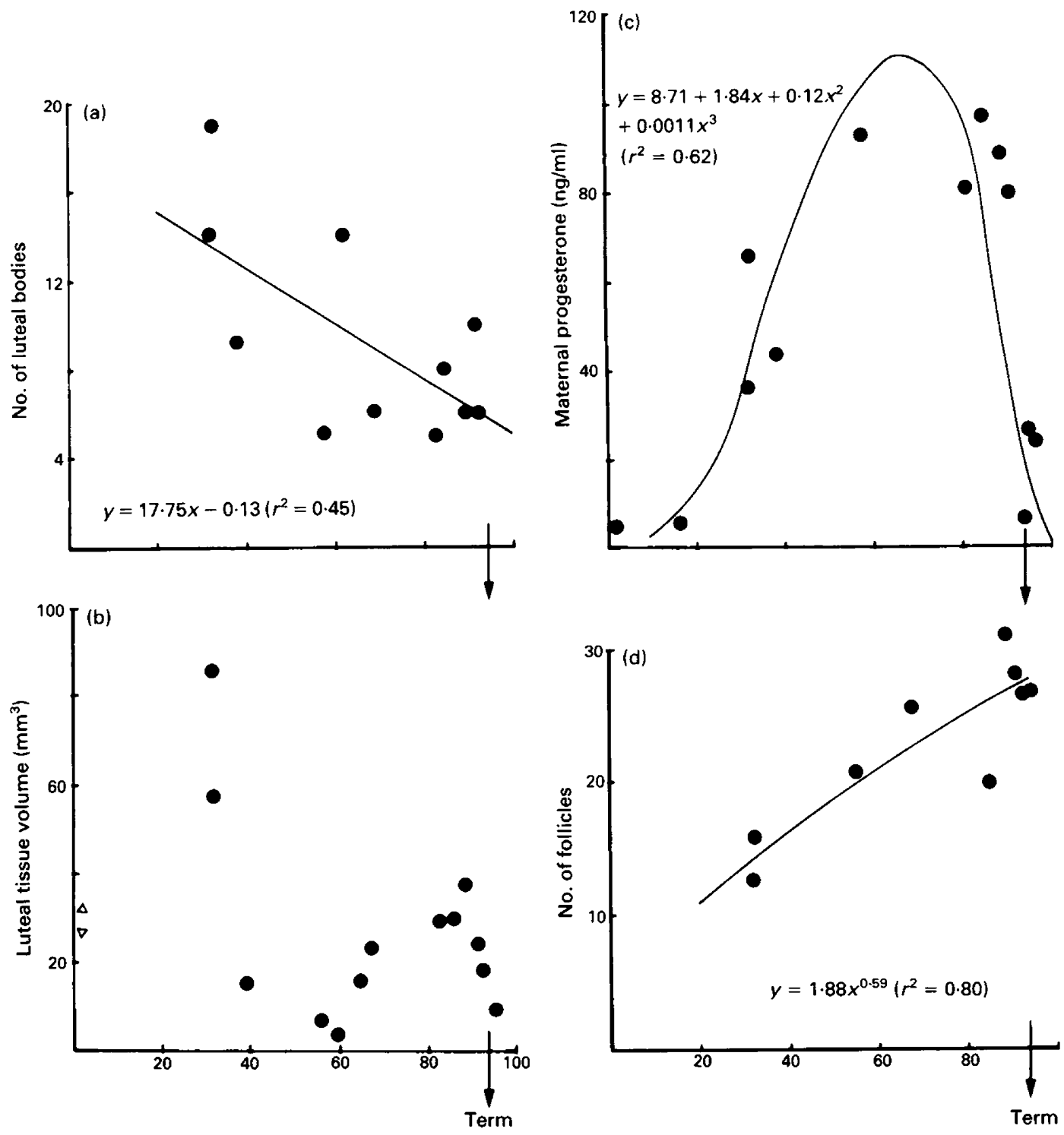

Fetal age (days)

Fig. 1. The relationships between (a) total number of luteal bodies in maternal ovaries; (b) total luteal volume in maternal ovaries. (c) circulating maternal plasma concentration of progesterone; and (d) number of antral follicles in maternal ovaries and fetal age. In b, $\Delta$ denotes volumes observed in ovaries of females with a perforated vaginal membrane. 
The total volume of luteal tissue per female was not affected by fetal age (Fig. 1b) or related to circulating concentrations of plasma progesterone measured in these females, although maternal plasma progesterone values were correlated with fetal age (Fig. 1c). The third degree polynomial function describing the curve relating maternal progesterone values to fetal age suggested a peak $(110 \mathrm{ng} / \mathrm{ml})$ in progesterone concentrations at 65-70 days post coitum (Fig. 1c), which corresponds with values recorded for captive females (van Aarde, 1984; van Aarde \& Potgieter, 1986).

Follicular activity, as suggested by the presence of various numbers of antral follicles (13-31/female) in the ovaries of pregnant females, occurred throughout pregnancy. Most of these follicles were in the process of luteinization or atresia and their numbers increased significantly with an increase in fetal age (Fig. 1d). The volume of the largest follicle in ovaries of pregnant females varied from $7 \cdot 7$ to $126.5 \mathrm{~mm}^{3}$ with most $(67.7 \%)$ varying from 10.0 to $30.0 \mathrm{~mm}^{3}$. The size of the largest follicle in these females was not affected by fetal age $\left(r^{2}=0.01\right)$ and also not related $\left(r^{2}=0.09\right)$ to circulating plasma concentrations of oestradiol-17 $\beta$. No definite relationship between circulating maternal oestradiol- $17 \beta$ values and fetal age could be identified. In pregnant females oestradiol concentrations varied from $14 \cdot 2$ to $430 \cdot 0 \mathrm{pg} / \mathrm{ml}$.

During lactation. The stage of lactation (i.e. days post partum) of lactating females from which ovaries were available $(\mathrm{N}=9)$ could not be determined. The ovaries consisted predominantly of interstitial tissue and atretic antral follicles $\left(7.47-20.67 \mathrm{~mm}^{3}\right.$ in volume) and varying in number from 0 to 29 per ovary. Degenerating luteal bodies occurred in most of these ovaries with the number varying from 0 to 5 per ovary and 4 to 8 per female. Total volume varied from $3 \cdot 19$ to $8.38 \mathrm{~mm}^{3}$ and plasma progesterone values ranged from 0.74 to $7.64 \mathrm{ng} / \mathrm{ml}$.

Circulating concentrations of plasma oestradiol-17 $\beta$ in these samples varied from 20 to $170 \mathrm{pg} / \mathrm{ml}$, with the highest value being recorded for a female in which the uterus still contained bloody fluid and which had not yet involuted following parturition.

\section{Discussion}

The macro- and microscopic anatomy of the ovaries of the Cape porcupine is similar to that of New World hystricomorph rodents (see Weir \& Rowlands, 1974, for review) with the presence of accessory corpora lutea and other luteal bodies being the most outstanding features. The formation of accessory corpora lutea is regarded as important in supplementing progesterone during pregnancy (Tam, 1974). The necessity for the development of excess luteal tissue in the chinchilla (Chinchilla laniger), agouti (Dasyprocta sp.), acouchi (Myoprocta pratti), mountain viscacha (Lagidium boxi) and Canadian porcupine (Erethizon dorsatum) is apparently related to the long gestation period (Weir \& Rowlands, 1974).

In porcupines, luteal bodies are formed during pregnancy (93-94 days) and primary corpora lutea and accessory luteal bodies are histologically similar (and thus presumably functionally similar, see Tam, 1974) and persist throughout pregnancy with the number of luteal bodies decreasing throughout gestation. The poor relationship between luteal activity, as suggested by volume, and circulating concentrations of progesterone, may, however, be indicative of extra-ovarian sources of progesterone production. Amoroso \& Perry (1977) did, however, warn against the assumption that endocrine activity can be adjudged from the histological appearance or size of the corpus luteum only. Rowlands et al. (1970) concluded that changes in plasma progesterone concentrations in the acouchi closely follow the pattern of growth and decline in volume of the corpus luteum. Volumetric changes of the primary corpora lutea during pregnancies in other hystricomorph rodents have been investigated by Rowlands (1956), Rowlands \& Heap (1966) and Weir $(1967,1974)$ and differ from species to species, but are similar in the guinea-pig and chinchilla, which differ from the coypu (Myocastor coypus) and the cuis (Galea musteloides). In the chinchilla, agouti, acouchi and Canadian porcupine, primary corpora lutea are conspicuous for the first part of gestation and then the ovary becomes "cluttered by histologically identical CL" (Weir \& Rowlands, 1974). 
Peak values of progesterone recorded during this study $(110 \mathrm{ng} / \mathrm{ml})$ were lower than those reported for pregnant guinea-pigs $(\sim 200 \mathrm{ng} / \mathrm{ml})$, casiragua (Proechimys semispinosus) and cuis ( $\sim 250 \mathrm{ng} / \mathrm{ml}$ ) and higher than those observed in the degu (Octodon degus), plains viscacha (Lagostomus maximus) and acouchi $(50-60 \mathrm{ng} / \mathrm{ml}$; Rowlands et al., 1970; Heap et al., 1981). These low levels are, however, higher than those recorded in hamsters, ewes and cows (see Tam, 1974).

Oestradiol-17 $\beta$ profiles throughout pregnancy in hystricomorph rodents have been published only for the guinea-pig (Challis et al., 1971) and peak values (mean $31.0 \pm 5.2 \mathrm{pg} / \mathrm{ml}$ ) were considerably lower than in the porcupine $(430 \mathrm{pg} / \mathrm{ml})$. The lack of a definite trend in oestradiol- $17 \beta$ secretion in culled porcupine females probably results from large individual variation. Values for captive females sampled serially, however, remained low until Days 20-25 post coitum and the rates of increase approximate those of progesterone and progesterone-binding plasma proteins (PBPP) (van Aarde, 1984). Oestradiol-17 $\beta$ values, however, remained high until before parturition while progesterone concentrations were decreasing. Oestradiol-17 $\beta$ values in pregnant females were also higher than those recorded in cyclic females (van Aarde, 1985a). Oestradiol-17 $\beta$ is known as a major metabolite of progesterone in marmosets, Callithrix jacchus (Shackleton, 1974), and increases in circulating concentrations in porcupines may therefore be ascribed to an increase in the metabolic breakdown of progesterone. However, this is at variance with the suggested decrease in progesterone metabolic clearance rate due to the increase in PBPP levels (van Aarde, 1984). A follicular source of oestradiol is likely since antral follicles occurred in the ovaries of pregnant porcupines throughout gestation, with the number of large follicles increasing significantly with an increase in gestation period. In the plains viscacha, follicles develop throughout pregnancy to ovulatory size (Weir, 1971a) and follicular cycles terminating in degeneration occur continually in pregnant guinea-pigs (Perry \& Rowlands, 1962). These may serve as a source of oestradiol-17 $\beta$ and thus explain the observed trend. Challis et al. (1971) suggested that ovarian oestrogen secretion may continue throughout gestation in guinea-pigs but ascribed the low levels of unconjugated oestrogens to a rapid rate of clearance.

Circulating concentrations of hormones do not necessarily reflect their rates of secretion and as yet nothing is known about the metabolism or production of steroids and the relative contribution of the ovary, uterus, placenta and conceptus in the porcupine. The histological appearance of ovaries from lactating females and the consistently low levels of progesterone during lactation confirm the inhibitory effects of lactation on cyclic ovarian activity in the porcupine (see van Aarde, 1985b). Lactation anoestrus is not unusual for hystricomorph rodents and has been reported for the chinchilla (Weir, 1967), the cuis (Rood \& Weir, 1970), the green acouchi (Weir, 1971b) and the plains viscacha (Weir, 1971c).

Financial support was provided by the University of Pretoria, the Council for Scientific and Industrial Research and the Transvaal Branch of the Wildlife Society who twice awarded the Charles Astley Maberly Memorial Scholarship to R.J. van A. We thank the staff of the Nature Conservation and Management Branch of the Provincial Administration of the Orange Free State for assistance and Amanda Nel for the figures.

\section{References}

Abraham, E.G. (1976) Radioimmunoassay of oestradiol-17ß in plasma. In Methods of Hormone Analysis, pp. 537-571. Eds H. Breuer, D. Hamel \& H. L. Krüskemper. George Thieme Verlag, Stuttgart.

Amoroso, E.C. \& Perry, J.S. (1977) Ovarian activity during gestation. In The Ovary, 2nd edn, pp. 316-398. Eds S. Zuckerman \& B. J. Weir. Academic Press, New York.
Challis, J.R.G., Heap, R.B. \& Ilingworth, D.V. (1971) Concentrations of oestrogen and progesterone in the plasma for non-pregnant, pregnant and lactating guinea-pigs. J. Endocr. 51, 333-345.

Furr, B.J.A. (1973) Radioimmunoassay of progesterone in peripheral plasma of the domestic fowl in various physiological states and in follicular venous plasma. Acta endocr., Copenh. 72, 89-100. 
Gosling, L.M. (1980) Reproduction of the Himalayan porcupine (Hystrix hodgsoni) in captivity. J. Zool., Lond. 192, 546-549.

Harrison, R.J. Weir, B.J. (1977) Structure of the mammalian ovary. In The Ovary, 2nd edn, pp. 113-217. Eds S. Zuckerman \& B. J. Weir. Academic Press, New York.

Heap, R.B. \& Illingworth, D.V. (1974) The maintenance of gestation in the guinea-pig and other hystricomorph rodents: Changes in the dynamics of progesterone metabolism and the occurrence of progesterone-binding globulin (PBG). Symp. zool. Soc. Lond. 34, 385-415.

Heap, R.B., Ackland, N. \& Weir, B.J. (1981) Progesterone-biding proteins in plasma of guinea-pigs and other hystricomorph rodents. J. Reprod. Fert. 63, $477-489$.

Huggett, A. St G. \& Widdas, W.F. (1951) The relationship between mammalian foetal weight and conception age. J. Physiol., Lond. 114, 306-317.

Jeficoate, S.L. (1981) Efficiency and Effectiveness in the Endocrine Laboratory. Academic Press, London.

Perry, J.S. \& Rowlands, I.W. (1962) The ovarian cycle in vertebrates. In The Ovary, 1st edn, pp. 275-309. Ed. S. Zuckerman. Academic Press, New York.

Rood, J.P. Weir, B.J. (1970) Reproduction in female wild guinea-pigs. J. Reprod. Fert. 23, 393-409.

Rowlands, I.W. (1956) The corpus luteum of the guinea-pig. Ciba Fdn Colloq. Ageing 2, 69-83.

Rowlands, I.W. \& Heap, R.B. (1966) Histological observations on the ovary and progesterone levels of the coypu, Myocastor coypus. Symp. zool. Soc. Lond. 15, 335-352.

Rowlands, I.W., Tam, W.H. \& Kleiman, D.G. (1970) Histological and biochemical studies on the ovary and progesterone levels in the systemic blood of the green acouchi (Myoprocta pratti). J. Reprod. Fert. 22, 533-545.

Shackleton, C.H.D. (1974) Progesterone and oestrogen metabolism in the pregnant marmoset Callithrix jacchus. J. Steroid Biochem. 15, 597-600.

Skinner, J.D., van Aarde, R.J. \& van Jaarsveld, A.S. (1984) Adaptations in three species of large mammals (Antidorcas marsupialis, Hystrix africaeaustralis, Hyaena brunnea) to arid environments. S. Afr. J. Zool. 19, 82-86.
Tam, W.H. (1974) The synthesis of progesterone in some hystricomorph rodents. Symp. zool. Soc. Lond. 34, 363-384.

Thomè, G. \& Thomè, H. (1980) Contribution a l'etude du porc-epic Hystrix indica indica Kerr, 1792 (Rodentia). Mammalia 44, 523-529.

van Aarde, R.J. (1984) Reproduction in the porcupine Hystrix africaeaustralis Peters. D.Sc. thesis, University of Pretoria, Pretoria.

van Aarde, R.J. (1985a) Circulating progesterone and oestradiol-17 $\beta$ concentrations in cyclic Cape porcupines, Hystrix africaeaustralis. J. Reprod. Fert. 75, 583-591.

van Aarde, R.J. (1985b) Reproduction in captive female Cape porcupines (Hystrix africaeaustralis). J. Reprod. Fert. 75, 577-582.

van Aarde, R. J. \& Potgieter, H. C. (1986) Circulating progesterone, progesterone-binding proteins and oestradiol- $17 \beta$ concentrations in the pregnant Cape porcupine, Hystrix africaeaustralis. J. Reprod. Fert. 76, 561-567.

Weir, B.J. (1967) Aspects of reproduction in some hystricomorph rodents. Ph.D. thesis, University of Cambridge.

Weir, B.J. (1971a) The reproductive organs of the female Plains viscacha, Lagostomus maximus. J. Reprod. Fert. 25, 365-373.

Weir, B.J. (1971b) Some observations on reproduction in the female green acouchi, Myoprocta pratti. $J$. Reprod. Fert. 75, 577-582.

Weir, B.J. (1971c) The reproductive physiology of the plains viscacha, Lagostomus maximus. J. Reprod. Fert. 25, 355-363.

Weir, B.J. (1974) Reproductive characteristics of hystricomorph rodents. Symp. zool. Soc. Lond. 34, 265-301.

Weir, B.J. \& Rowlands, I.W. (1974) Functional anatomy of the hystricomorph ovary. Symp. zool. Soc. Lond. 34, 303-332. 